\title{
Current management of parainfluenza pneumonitis in immunocompromised patients: a review
}

This article was published in the following Dove Press journal:

Infection and Drug Resistance

7 August 2012

Number of times this article has been viewed

\author{
Ann R Falsey \\ University of Rochester, Rochester \\ General Hospital, Rochester, \\ NY, USA
}

\begin{abstract}
Parainfluenza viruses (PIV) are common respiratory viruses that belong to the Paramyxoviridae family. PIV infection can lead to a wide variety of clinical syndromes ranging from mild upper respiratory illness to severe pneumonia. Severe disease can be seen in elderly or chronically ill persons and may be fatal in persons with compromised immune systems, particularly children with severe combined immunodeficiency disease syndrome and hematopathic stem cell transplant recipients. At present, there are no licensed antiviral agents for the treatment of PIV infection. Aerosolized or systemic ribavirin in combination with intravenous gamma globulin has been reported in small, uncontrolled series and case reports of immunocompromised patients. A number of agents show antiviral activity in vitro and in animals, but none are currently approved for human use.
\end{abstract}

Keywords: parainfluenza virus, antiviral agents, immunocompromised host

\section{Introduction}

Parainfluenza viruses (PIV) are common respiratory viruses that belong to the Paramyxoviridae family and include four serotypes and two subtypes $(1,2,3$, 4a, and $4 \mathrm{~b}) .{ }^{1}$ PIV infection leads to a wide variety of clinical syndromes ranging from mild upper respiratory illness (URI) to severe pneumonia. ${ }^{2}$ PIV-1 tends to cause biennial fall epidemics and accounts for approximately $30 \%-50 \%$ of cases of croup in young children. ${ }^{3}$ PIV-2 is not as common as other serotypes and may cause alternating outbreaks with PIV-1, and most children are infected between the ages of 2 and 5 years. PIV-3 affects younger children and is second only to respiratory syncytial virus (RSV) as a cause of bronchiolitis and pneumonia in children less than 6 months old. ${ }^{2}$ It is estimated that $12 \%$ of hospitalizations for lower respiratory tract infection (LRTI) in children are due to PIV. PIV-4 affects older children and is the least common serotype. Because immunity is incomplete, reinfections occur throughout life and are generally mild, self-limited illnesses in young healthy adults. Severe disease can be seen in elderly or chronically ill persons and can be fatal in persons with compromised immune systems. ${ }^{1}$ Severe giant cell pneumonia has been reported in children with severe combined immunodeficiency disease syndrome (SCIDS), solid organ, and hematopathic stem cell transplant (HSCT) recipients. ${ }^{4-6}$ This review will focus on PIV infection in immunocompromised patients, the antiviral therapy in development, and current management of PIV in this patient population.
Correspondence: Ann R Falsey Infectious Disease Unit, Rochester General Hospital, I 425 Portland Avenue, Rochester, NY, I462I USA Tel +15859225168 Fax + I5 859224339 Email ann.falsey@rochestergeneral.org 


\section{Virology}

The parainfluenza viruses are enveloped negative sense RNA viruses. ${ }^{1}$ The genome, unlike influenza, is nonsegmented, $\sim 15,000$ nucleotides in length, and encodes six structural proteins. ${ }^{1,7}$ The virus has two membrane proteins, the hemagglutinin neuraminidase (HN) and the fusion protein (F) (Figure 1). ${ }^{7} \mathrm{HN}$ recognizes sialic acid-containing glycolipids and glycoproteins of the target host cell and allows binding. ${ }^{8}$ $\mathrm{HN}$ receptor interaction is needed for $\mathrm{F}$ protein triggering and after fusion with the cell membrane; the virus is uncoated and released into the cytoplasm (Figure 2). ${ }^{7,9}$ After early events, primary transcription occurs, antigenome RNA is synthesized, the virus is assembled, and finally the new virus buds and is released. $\mathrm{HN}$ also acts as a sialidase to remove sialic acid from the virus particles and prevent self-aggregation. Recent elucidation of protein structure and functions has furthered the development of new antiviral agents for the treatment of PIV infection.

\section{Immunology}

Host defense against PIV is mediated by humoral and cellular immunity. Antibodies to the two surface glycoproteins, $\mathrm{F}$ and $\mathrm{HN}$, are neutralizing and antibodies to either protein can protect against PIV challenge. ${ }^{10}$ Secretory IgA develops after natural infection and has been shown to neutralize virus and ameliorate disease. ${ }^{1}$ Cytotoxic $\mathrm{T}$ lymphocyte

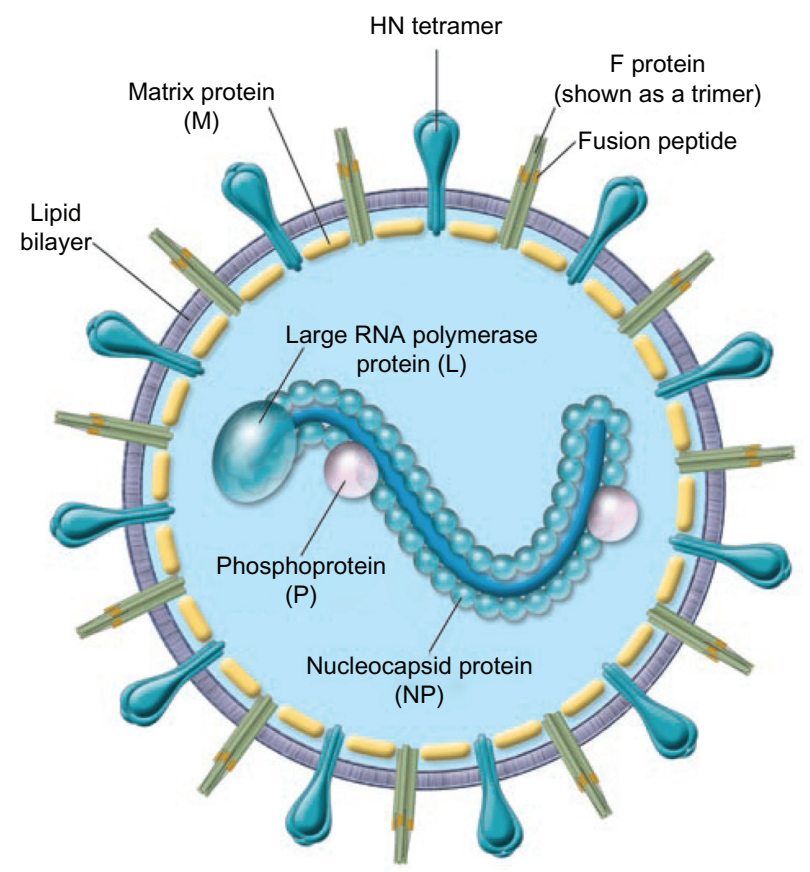

Figure I Schematic of the parainfluenza virion.

(C) 2005, American Society for Clinical Investigation. Reproduced with permission from Moscona A. Entry of parainfluenza virus into cells as a target for interrupting childhood respiratory disease. J Clin Invest. 2005; I 15(7):1688-1698.

Abbreviation: $\mathrm{HN}$, Hemagglutinin-neuraminidase protein. responses appear to play a role in the clearance of the virus from the lower airways in hamster and mouse models of PIV infection. ${ }^{11,12} \mathrm{~T}$ cell epitopes have been demonstrated on the $\mathrm{HN}, \mathrm{P}$, and NP proteins of PIV. ${ }^{1,13}$

\section{PIV infection in immunocompromised hosts}

The devastating effects of PIV infection in immunocompromised persons were first recognized in children with SCIDS, where giant cell pneumonia has been demonstrated at autopsy. ${ }^{14,15}$ This rare genetic disorder is characterized by primary deficiency of $\mathrm{T}, \mathrm{B}$, and NK cell-mediated immunity that predispose afflicted patients to serious infections, including respiratory viruses. Persistent respiratory tract infection and shedding has been observed in SCID and HIV patients. ${ }^{1,4}$ The natural history of PIV infection in HIV patients is not well defined, but severe illness appears uncommon unless significant $\mathrm{T}$ cell dysfunction has occurred. Severe PIV infection has also been observed in patients with hematologic malignancies undergoing chemotherapy. ${ }^{16}$ High rates of pneumonia (55\%) and death $(27 \%)$ have been noted, with low lymphocyte counts and the presence of pneumonia independently associated with risk of death. The largest immunocompromised patient populations affected by PIV infection are solid organ and HSCT recipients. ${ }^{5,6,17-23}$ The first report describing the clinical features and outcomes of PIV infection in solid organ transplant patients was in 1979 and involved 16 kidney transplant recipients..$^{24}$ Although no deaths occurred, an increased rate of acute graft rejection was noted. Among heart and lung transplant patients with PIV infection, $82 \%$ developed acute allograft refection and $32 \%$ developed bronchiolitis obliterans. ${ }^{20}$ Using culture direct immunofluorescence testing, PIV infection rates range from $2.2 \%$ to $14 \%$ among pediatric and adult HSCT transplant patients. ${ }^{4,17,22,25-28}$ More recently, higher rates of infection and asymptomatic shedding have been observed using new sensitive molecular diagnostic tests. ${ }^{29}$ Most infections begin with typical URI symptoms and lowgrade fever. ${ }^{6,18}$ Sinusitis may be seen on imaging studies in approximately $40 \%$ of patients. ${ }^{17}$ Progression from URI to lower tract disease is common with rates ranging from $18 \%$ to $77 \% .^{17,18,27,30}$ Risk of progression is associated with steroid use and lymphopenia and may be less with nonmyeloablative conditioning. ${ }^{16,22,23}$ Radiographic findings can be variable with focal or diffuse interstitial and alveolar interstitial infiltrates described.${ }^{18}$ Risk of death once pneumonia has developed can be very high ranging from $25 \%$ to $45 \% .{ }^{5}$ Extra pulmonary manifestations may also occur with parotitis, and dissemination to the brain, myocardium, and pericardium have been 


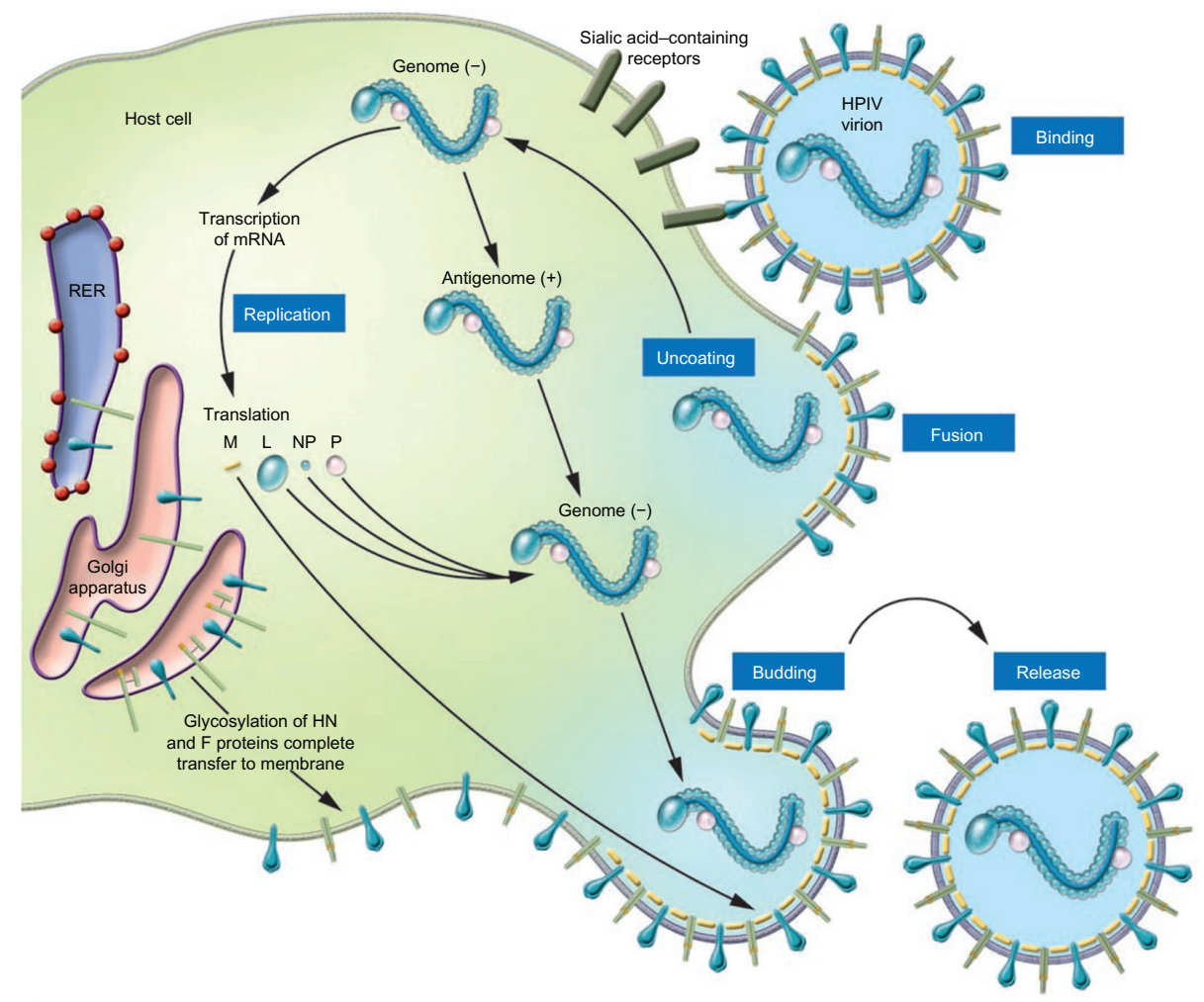

Figure 2 Schematic illustration of the parainfluenza life cycle.

(C) 2005, American Society for Clinical Investigation. Reproduced with permission from Moscona A. Entry of parainfluenza virus into cells as a target for interrupting childhood respiratory disease. J Clin Invest. 2005; I I5(7): I688-1698.

Abbreviation: RER, rough endoplasmic reticulum; HPIV, human parainfluenza virus; L, large RNA polymerase protein; M, matrix protein; NP, nucleocapsid protein; $P$, phosphoprotein.

described. ${ }^{31,32}$ Survival from acute PIV infection has been associated with significant declines in lung function at 1 year post transplant. ${ }^{20,33}$ Interestingly, in one study of HSCT patients, decline in airflow in PIV-infected patients was noted even among patients with URI symptoms alone..$^{33}$

\section{Therapy}

Presently there are no licensed antiviral agents for the treatment of PIV infection. Treatment is primarily symptomatic; aerosolized or systemic ribavirin in combination with intravenous gamma globulin has been reported in small, uncontrolled series, and case reports. A number of agents show antiviral activity in vitro and in animals.

\section{Ribavirin}

Ribavirin is a nucleoside analogue that has broad activity in vitro against many RNA and DNA viruses. ${ }^{34}$ Aerosolized ribavirin is currently licensed for the treatment of severe RSV in young children and oral an intravenous ribavirin has been used for the treatment of other viral infections such as hepatitis $\mathrm{C}$ and Lassa fever. Aerosolized ribavirin is generally well tolerated with mild skin and conjunctival irritation reported, although increased cough and bronchospasm may occur., ${ }^{4,35}$
In addition, teratogenicity in rodents has been reported and therefore it is recommended that pregnant health care workers avoid exposure. Systemic ribavirin can be associated with a reversible hemolytic anemia. ${ }^{4,25} \mathrm{~A}$ number of mechanisms have been proposed for the antiviral effect of ribavirin and include: decreased guanosine- 5 '-triphosphate (GTP) pools; inhibition of genomic RNA capping; direct inhibition of viral encoded polymerases; and increased mutation leading to error catastrophes and an immunomodulatory effect. ${ }^{4}$ Ribavirin appears to polarize the human $\mathrm{T}$ cell response towards a type 1 cytokine profile mediated by interleukin- 2 , INF- $\gamma$, and TNF- $\alpha .{ }^{36}$

Unfortunately, most of the information regarding the clinical utility of ribavirin comes from case reports or small, uncontrolled series. ${ }^{25,26,35-38}$ In children with SCIDS and PIV infection, aerosolized ribavirin has been administered over long periods of time (3-10 months) without apparent toxicity. ${ }^{4}$ Although ribavirin has been well tolerated, the efficacy for the treatment of PIV infection is difficult to determine, as most case series involve small numbers, different routes of administration, combination treatment with intravenous gamma globulin (IVIG), and different patient populations. The majority of data are in HSCT patients and consensus indicates that ribavirin is not effective for PIV 
pneumonia when given late in the course of illness, especially if respiratory failure has ensued..$^{17,22,27}$ Some reports suggest a modest benefit if the drug is given at the early stage of upper respiratory tract involvement, but this is controversial because of the lack of controlled trials. Most of the studies of HSCT patients report ribavirin treatment of both URI and LRTI PIV infection and demonstrate no clear benefit of ribavirin treatment (Table 1). Wendt et al reported PIV infection in 12 adults and 15 children undergoing $\mathrm{HSCT}^{27}$ Seventy percent had lower respiratory tract involvement and of those, $32 \%$ developed respiratory failure. Nine subjects received inhaled ribavirin with a survival rate of $78 \%$, which was the same as those who were not treated. Notably, treatment was started late in the course of symptoms, on average after 11 days of illness. Nichols et al reported the treatment and outcomes of 253 HSCT patients with PIV infection; ${ }^{22}$ $13 \%$ had LRTI at presentation and another $13 \%$ progressed from URI to pneumonia. The use of ribavirin with or without IVIG was assessed in patients with LRTI and had no effect on 30-day mortality, and the risk of death was highest in patients with bacterial or fungal copathogens (Figure 3).

Although the efficacy of ribavirin for the treatment of LRTI is debatable, early treatment to prevent progression to pneumonia remains an unanswered question. In addition, the role of ribavirin to prevent long-term pulmonary sequelae deserves further exploration since significant airflow decline after PIV infection has been shown in both HSCT and heart and lung transplant recipients. ${ }^{20,33}$ In a small cohort of heartlung transplant patients with PIV infection, the use of IVIG, steroids, and ribavirin was associated with a slower decline in lung function compared to historical controls. ${ }^{5}$

\section{Other antiviral agents}

A number of chemical compounds have shown in vitro activity against PIV and include: protein synthesis inhibitors (puromycin); benzothiazole derivative; 1, 2, 4-thiadiazol-2 ylcyanamide; carbocyclic-3-deezaadenosine; ascorbic acid; calcium elenolate; and extracts of Sanicula europaea leaves. However, none of these agents have clinical applications. ${ }^{1}$ Amantadine shows activity against PIV in high concentration in vitro, but does not decrease URI symptoms in PIV challenged adults. ${ }^{1}$

Recent work has focused on transcription inhibitors, and Mao et al have demonstrated novel small molecules (C5 and C7) with potent anti-PIV activity. ${ }^{9,39}$ The $\mathrm{C}$ protein of PIV is a multifactorial accessory protein that inhibits viral transcription and interferon signaling. Removal of the $\mathrm{N}$-terminal 25 amino acids of the C-protein potentiates the inhibitory activity of the protein and shows promise as a PIV antiviral agent. ${ }^{39}$

Another approach has been to target the binding or neuraminidase function of the $\mathrm{HN}$ protein. The $\mathrm{HN}$ protein recognizes sialic acid-containing glycolipids and glycoproteins on the host target cells and allows binding to occur. It also acts as a sialidase to remove sialic acid from the virus particles to prevent self-aggregation, and work is continuing to identify novel sialic acidase inhibitors. ${ }^{8}$ DAS181 is a novel inhaled recombinant sialidase fusion protein that interferes with the initial binding of $\mathrm{HN}$ with the target cell sialic acidcontaining receptor. DAS181 contains the catalytic domain of actinomyces viscous sialidase and the heparin-binding domain of human amphiregulin to prolong DAS181 retention on the epithelial surface. ${ }^{7,40}$ The drug was developed as an antiviral agent for influenza. ${ }^{41}$ Since sialic acid residues serve as the cellular receptors for both influenza and PIV, DAS181 has been explored for PIV antiviral activity. Compassionate use of this agent was recently reported in a 63-year-old woman with acute myelogenous leukemia (AML) post HSCT, who developed PIV pneumonia. ${ }^{40}$ Administration of the inhaled product was associated with clinical improvement and decreased PIV shedding; however, symptoms and shedding recurred 2 weeks

Table I Reports of ribavirin treatment of PIV infection in HSCT patients

\begin{tabular}{|c|c|c|c|c|c|c|}
\hline Year & Author (ref) & $\begin{array}{l}\mathrm{N} \text { of PIV } \\
\text { cases }\end{array}$ & N of LRTI & $\begin{array}{l}\text { Route of } \\
\text { administration }\end{array}$ & $\begin{array}{l}\mathbf{N} \text { surviving/ } \\
\mathbf{N} \text { treated }(\%)\end{array}$ & $\begin{array}{l}\mathbf{N} \text { surviving/ } \\
\mathbf{N} \text { not treated (\%) }\end{array}$ \\
\hline 1992 & Wendt et $\mathrm{al}^{27}$ & 27 & 19 & Aer & $7 / 9(78)$ & 14/I8 (78) \\
\hline 1996 & Lewis et $\mathrm{al}^{17}$ & 61 & 27 & Aer & $3 / 5(60)$ & $5 \mathrm{I} / 56(9 \mathrm{I})$ \\
\hline 1997 & Sparrelid et a $\left.\right|^{35}$ & 3 & 2 & $\mathrm{PO} / \mathrm{IV}$ & $3 / 3(100)$ & NA \\
\hline 2000 & Chakrabarti et $\mathrm{al}^{36}$ & 5 & 4 & Aer/PO/IV & $5 / 5(100)$ & NA \\
\hline 2001 & Chakrabarti et $\mathrm{al}^{25}$ & 5 & 3 & $\mathrm{PO}$ & $4 / 5(80)$ & NA \\
\hline 2001 & Elizaga et $\mathrm{a}^{26}$ & 24 & 14 & Aer/IV & $12 / 18(67)$ & $4 / 6(67)$ \\
\hline 2001 & Lujan-Zilbermann et $\mathrm{al}^{21}$ & 12 & 7 & Not specified & $2 / 3(67)$ & $9 / 9(100)$ \\
\hline 2001 & Nichols et $\mathrm{al}^{22}$ & 253 & 55 & Aer + /- IVIG & $22 / 31(72)$ & $14 / 24(58)$ \\
\hline 2006 & Dignan et $\mathrm{a}^{28}$ & 24 & 12 & Aer/IV & $7 / 8(88)$ & $16 / 16(100)$ \\
\hline
\end{tabular}

Abbreviations: PIV, parainfluenza virus; HSCT, hematopathic stem cell transplant; N, number; LRTI, lower respiritory tract infection; Aer, aerosolized; PO, oral; IV, intravenous; IVIG, intravenous gamma globulin; NA, not available. 


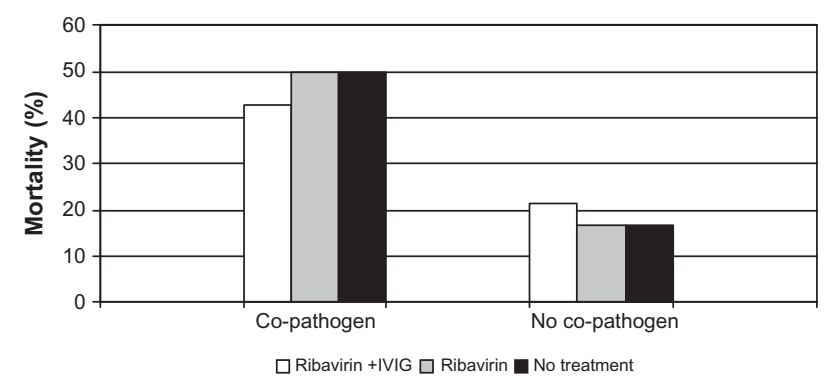

Figure 3 Percent mortality broken down by treatment group and presence or absence of co-pathogens.

Figure (c) 200I, American Society for Blood and Marrow Transplantation. Adapted with permission from Nichols WG, Gooley T, Boeckh M. Community-acquired respiratory syncytial virus and parainfluenza virus infections after hematopoietic stem cell transplantation: the Fred Hutchinson Cancer Research Center experience. Biol Blood Marrow Transplant. 200I;7 Suppl:IIS-I5S. ${ }^{22}$

Abbreviation: IVIG, intravenous gammaglobulin.

after stopping treatment when she presented with relapsed AML. The drug was well tolerated without discernible toxicity and is a promising new therapy for PIV infection.

The discovery of the three-dimensional structure of the PIV HN has allowed the design of inhibitors that fit into the binding site of the globular head. HN receptor interaction is not only needed for binding to the target cell but is also needed for $\mathrm{F}$ protein triggering and fusion. ${ }^{7}$ Additional promising agents are $\mathrm{HN}$ inhibitors, BCX 2798, and BCX 2855, which bind to the conserved catalytic binding site of PIV. ${ }^{42,43}$ These agents effectively inhibit PIV growth in the mouse model and mice treated intranasally showed decreased PIV shedding and inflammatory histopathologic changes in the lungs.

The F protein mediates fusion of the virus and host cell and is another alternative antiviral target. Rho A, a small GTPase, facilitates syncytial formation. ${ }^{44}$ Pastey et al reported that a Rho A-derived peptide inhibited both RSV and PIV-3 in vitro by inhibiting cell-to-cell fusion in vivo by reducing the peak titer by 100 -fold in RSV-infected mice. ${ }^{44}$ Synthetic peptides derived from heptad repeat domain of HIV gp41 have been shown to be potent inhibitors of HIV infection and fusion. ${ }^{45}$ Because fusogenic viruses, including PIV, demonstrate amino acid sequence homology at the amino termini with HIV, researchers have investigated the possibility of finding similar functional homologues for PIV. ${ }^{45}$ Lambert et al were successful at identifying such a peptide for PIV-3 that blocked PIV-mediated syncytia formation in cell culture. ${ }^{45}$

\section{Immunomodulators and antibody therapy}

Nonspecific immunostimulators have been explored as potential treatments for PIV infection including dihydroheptaprenol, imiquimod, and interferon (IFN) alpha and gamma. ${ }^{1}$
In vitro IFN inhibits viral transcription and has been shown to reduce PIV replication in A549 cells by 100 -fold. ${ }^{46}$ Immunoglobulins have demonstrated some antiviral efficacy in the cotton rat model of PIV-3 infection. ${ }^{47}$ Using two lots of commercial, human-pooled IVIG to treat PIV-infected cotton rats, Ottolini et al demonstrated a significant decrease in lung PIV titers, although nasal titers were unchanged with treatment. ${ }^{47}$ In subsequent studies, the combination of steroids with IVIG produced the most favorable results. ${ }^{48,49}$ While the use of IVIG leads to improved viral clearance, there was no effect on inflammatory changes in the lungs and treatment with steroids alone lead to decreased lung pathology but a 10-fold increase in viral growth. ${ }^{49}$ The combination of IVIG and steroids demonstrated both favorable effects but rebound of pathology was observed if treatment was not continued for eight or more days.

\section{Conclusion}

PIV infection in immunocompromised patients is relatively common and can be associated with a spectrum of diseases, ranging from mild URI symptoms to severe respiratory failure and death. Risk of progression to pneumonia appears to be related to use of steroids and lymphopenia. Once pneumonia has developed, death rates are high and at the present time, effective antiviral therapy is not available. Randomized controlled trials of ribavirin to prevent progression of PIV from the upper to the lower respiratory tract are needed. New information on the structure and function of PIV proteins and the cellular processes of the PIV life cycle should provide new areas of research for antiviral agents.

\section{Disclosure}

Dr Falsey has consulted for Medimmune, AstraZeneca, Novartis, Novavax, GlaxoSmithKline, and Sanofi Pasteur. There was no conflict of interest for any of the materials presented in this manuscript.

\section{References}

1. Henrickson KJ. Parainfluenza viruses. Clin Microbiol Rev. 2003;16(2): 242-264.

2. Hall CB. Respiratory syncytial virus and parainfluenza virus. $N$ Engl J Med. 2001;344(25):1917-1928.

3. Rihkanen H, Ronkko E, Nieminen T, et al. Respiratory viruses in laryngeal croup of young children. J Pediatr. 2008;152(5):661-665.

4. Stankova J, Carret AS, Moore D, et al. Long-term therapy with aerosolized ribavirin for parainfluenza 3 virus respiratory tract infection in an infant with severe combined immunodeficiency. Pediatr Transplant. 2007;11(2):209-213

5. Moss RB, Steigbigel RT, Sanders RL, Fang F. Perspective: emerging challenges in the treatment of influenza and parainfluenza in transplant patients. Adv Virol. 2011;2011:910930. Epub July 7, 2011. 
6. Boeckh M. The challenge of respiratory virus infections in hematopoietic cell transplant recipients. Br J Haematol. 2008;143(4):455-467.

7. Moscona A. Entry of parainfluenza virus into cells as a target for interrupting childhood respiratory disease. J Clin Invest. 2005;115(7): $1688-1698$.

8. Nishino R, Ikeda K, Hayakawa T, Takahashi T, Suzuki T, Sato M. Syntheses of 2-deoxy-2,3-didehydro-N-acetylneuraminic acid analogues modified by N-sulfonylamidino groups at the $\mathrm{C}-4$ position and biological evaluation as inhibitors of human parainfluenza virus type 1 . Bioorg Med Chem. 2011;19(7):2418-2427.

9. Mao H, Thakur CS, Chattopadhyay S, Silverman RH, Gudkov A, Banerjee AK. Inhibition of human parainfluenza virus type 3 infection by novel small molecules. Antiviral Res. 2008;77(2):83-94.

10. Spriggs MK, Murphy BR, Prince GA, Olmsted RA, Collins PL. Expression of the $\mathrm{F}$ and $\mathrm{HN}$ glycoproteins of human parainfluenza virus type 3 by recombinant vaccinia viruses: contributions of the individual proteins to host immunity. J Virol. 1987;61(11):3416-3423.

11. Henderson FW. Pulmonary cell-mediated cytotoxicity in hamsters with parainfluenza virus type 3 pneumonia. Am Rev Respir Dis. 1979;120(1):41-47.

12. Hou S, Doherty PC, Zijlstra M, Jaenisch R, Katz JM. Delayed clearance of Sendai virus in mice lacking class I MHC-restricted CD8+ T cells. J Immunol. 1992;149(4):1319-1325.

13. Dave VP, Allan JE, Slobod KS, et al. Viral cross-reactivity and antigenic determinants recognized by human parainfluenza virus type 1-specific cytotoxic T-cells. Virology. 1994;199(2):376-383.

14. Karp D, Willis J, Wilfert CM. Parainfluenza virus II and the immunocompromised host. Am J Dis Child. 1974;127(4):592-593.

15. Delage G, Brochu P, Pelletier M, Jasmin G, Lapointe N. Giant-cell pneumonia caused by parainfluenza virus. J Pediatr. 1979;94(3): 426-429.

16. Marcolini JA, Malik S, Suki D, Whimbey E, Bodey GP. Respiratory disease due to parainfluenza virus in adult leukemia patients. Eur J Clin Microbiol Infect Dis. 2003;22(2):79-84.

17. Lewis VA, Champlin R, Englund J, et al. Respiratory disease due to parainfluenza virus in adult bone marrow transplant recipients. Clin Infect Dis. 1996;23(5):1033-1037.

18. Wendt $\mathrm{CH}$, Hertz MI. Respiratory syncytial virus and parainfluenza virus infections in the immunocompromised host. Semin Respir Infect. 1995;10(4):224-231.

19. Whimbey E, Champlin RE, Couch RB, et al. Community respiratory virus infections among hospitalized adult bone marrow transplant recipients. Clin Infect Dis. 1996;22(5):778-782.

20. Vilchez RA, McCurry K, Dauber J, et al. The epidemiology of parainfluenza virus infection in lung transplant recipients. Clin Infect Dis. 2001;33(12):2004-2008.

21. Lujan-Zilbermann J, Benaim E, Tong X, Srivastava DK, Patrick CC, DeVincenzo JP. Respiratory virus infections in pediatric hematopoietic stem cell transplantation. Clin Infect Dis. 2001;33(7):962-968.

22. Nichols WG, Gooley T, Boeckh M. Community-acquired respiratory syncytial virus and parainfluenza virus infections after hematopoietic stem cell transplantation: the Fred Hutchinson Cancer Research Center experience. Biol Blood Marrow Transplant. 2001;7 Suppl:11S-15S.

23. Chakrabarti S, Avivi I, Mackinnon S, et al. Respiratory virus infections in transplant recipients after reduced-intensity conditioning with Campath-1H: high incidence but low mortality. Br J Haematol. 2002;119(4):1125-1132.

24. DeFabritus AM, Riggio RR, David DS, Senterfit LB, Cheigh JS, Stenzel KH. Parainfluenza type 3 in a transplant unit. JAMA. 1979;241(4): 384-386.

25. Chakrabarti S, Collingham KE, Holder K, Fegan CD, Osman H, Milligan DW. Pre-emptive oral ribavirin therapy of paramyxovirus infections after haematopoietic stem cell transplantation: a pilot study. Bone Marrow Transplant. 2001;28(8):759-763.

26. Elizaga J, Olavarria E, Apperley J, Goldman J, Ward K. Parainfluenza virus 3 infection after stem cell transplant: relevance to outcome of rapid diagnosis and ribavirin treatment. Clin Infect Dis. 2001;32(3):413-418.
27. Wendt CH, Weisdorf DJ, Jordan MC, Balfour HH Jr, Hertz MI. Parainfluenza virus respiratory infection after bone marrow transplantation. N Engl J Med. 1992;326(14):921-926.

28. Dignan F, Alvares C, Riley U, et al. Parainfluenza type 3 infection post stem cell transplant: high prevalence but low mortality. $J$ Hosp Infect. 2006;63(4):452-458.

29. Peck AJ, Englund JA, Kuypers J, et al. Respiratory virus infection among hematopoietic cell transplant recipients: evidence for asymptomatic parainfluenza virus infection. Blood. 2007;110(5):1681-1688.

30. Hodson A, Kasliwal M, Streetly M, MacMahon E, Raj K. A parainfluenza-3 outbreak in a SCT unit: sepsis with multi-organ failure and multiple co-pathogens are associated with increased mortality. Bone Marrow Transplant. 2011;46(12):1545-1550.

31. Frank JA Jr, Warren RW, Tucker JA, Zeller J, Wilfert CM. Disseminated parainfluenza infection in a child with severe combined immunodeficiency. Am J Dis Child. 1983;137(12):1172-1174.

32. Lange T, Franke G, Niederwieser D. Parotitis associated with a parainfluenza virus type 3 infection during aplasia after unrelated allogeneic stem cell transplantation. Leuk Lymphoma. 2006;47(8):1714-1715.

33. Erard V, Chien JW, Kim HW, et al. Airflow decline after myeloablative allogeneic hematopoietic cell transplantation: the role of community respiratory viruses. J Infect Dis. 2006;193(12):1619-1625.

34. Hall CB, McBride JT, Walsh EE, et al. Aerosolized ribavirin treatment of infants with respiratory syncytial viral infection. A randomized double-blind study. N Engl J Med. 1983;308(24):1443-1447.

35. Sparrelid E, Ljungman P, Ekelof-Andstrom E, et al. Ribavirin therapy in bone marrow transplant recipients with viral respiratory tract infections. Bone Marrow Transplant. 1997;19(9):905-908.

36. Chakrabarti S, Collingham KE, Holder K, Oyaide S, Pillay D, Milligan DW. Parainfluenza virus type 3 infections in hematopoetic stem cell transplant recipients: response to ribavirin therapy. Clin Infect Dis. 2000;31(6):1516-1518.

37. Wright JJ, O’Driscoll G. Treatment of parainfluenza virus 3 pneumonia in a cardiac transplant recipient with intravenous ribavirin and methylprednisolone. J Heart Lung Transplant. 2005;24(3): 343-346.

38. McIntosh K, Kurachek SC, Cairns LM, Burns JC, Goodspeed B. Treatment of respiratory viral infection in an immunodeficient infant with ribavirin aerosol. Am J Dis Child. 1984;138(3):305-308.

39. Mao H, Chattopadhyay S, Banerjee AK. N-terminally truncated C protein, CNDelta25, of human parainfluenza virus type 3 is a potent inhibitor of viral replication. Virology. 2009;394(1):143-148.

40. Chen YB, Driscoll JP, McAfee SL, et al. Treatment of parainfluenza 3 infection with DAS181 in a patient after allogeneic stem cell transplantation. Clin Infect Dis. 2011;53(7):e77-e80.

41. Triana-Baltzer GB, Sanders RL, Hedlund M, et al. Phenotypic and genotypic characterization of influenza virus mutants selected with the sialidase fusion protein DAS181. J Antimicrob Chemother. 2011;66(1):15-28.

42. Watanabe M, Mishin VP, Brown SA, et al. Effect of hemagglutininneuraminidase inhibitors BCX 2798 and BCX 2855 on growth and pathogenicity of Sendai/human parainfluenza type 3 chimera virus in mice. Antimicrob Agents Chemother. 2009;53(9):3942-3951.

43. Alymova IV, Watanabe M, Boyd KL, Chand P, Babu YS, Portner A. Efficacy of the novel parainfluenza virus haemagglutinin-neuraminidase inhibitor BCX 2798 in mice - further evaluation. Antivir Ther. 2009;14(7):891-898.

44. Pastey MK, Gower TL, Spearman PW, Crowe JE Jr, Graham BS. A RhoA-derived peptide inhibits syncytium formation induced by respiratory syncytial virus and parainfluenza virus type 3. Nat Med. 2000;6(1):35-40.

45. Lambert DM, Barney S, Lambert AL, et al. Peptides from conserved regions of paramyxovirus fusion (F) proteins are potent inhibitors of viral fusion. Proc Natl Acad Sci U S A. 1996;93(5):2186-2191.

46. Zhao H, De BP, Das T, Banerjee AK. Inhibition of human parainfluenza virus-3 replication by interferon and human MxA. Virology. 1996;220(2):330-338. 
47. Ottolini MG, Hemming VG, Piazza FM, Johnson SA, Darnell ME, Prince GA. Topical immunoglobulin is an effective therapy for parainfluenza type 3 in a cotton rat model. J Infect Dis. 1995;172(1):243-245.

48. Ottolini MG, Porter DD, Blanco JC, Prince GA. A cotton rat model of human parainfluenza 3 laryngotracheitis: virus growth, pathology, and therapy. J Infect Dis. 2002;186(12):1713-1717.
49. Prince GA, Porter DD. Treatment of parainfluenza virus type 3 bronchiolitis and pneumonia in a cotton rat model using topical antibody and glucocorticosteroid. J Infect Dis. 1996;173(3):598-608.

\section{Publish your work in this journal}

Infection and Drug Resistance is an international, peer-reviewed openaccess journal that focuses on the optimal treatment of infection (bacterial, fungal and viral) and the development and institution of preventive strategies to minimize the development and spread of resistance. The journal is specifically concerned with the epidemiology of antibiotic

\section{Dovepress}

resistance and the mechanisms of resistance development and diffusion in both hospitals and the community. The manuscript management system is completely online and includes a very quick and fair peerreview system, which is all easy to use. Visit http://www.dovepress.com/ testimonials.php to read real quotes from published authors.

Submit your manuscript here: http://www.dovepress.com/infection-and-drug-resistance-journal 